\title{
Satellite Image Data as Environmental Crime Evidence in the Field of Illegal Logging
}

\author{
Mahfud $^{1}$, Lena Farsia ${ }^{2}$, Nellyana Roesa ${ }^{3}$, Safrina ${ }^{4}$ \\ ${ }^{1}$ Faculty of Law, Universitas Syiah Kuala, Indonesia, \\ Email:mahfud.abdullah@unsyiah.ac.id \\ ${ }^{2}$ Faculty of Law,Universitas Syiah Kuala, Indonesia, \\ Email: farsia.lena@unsyiah.ac.id \\ ${ }^{3}$ Faculty of Law,Universitas Syiah Kuala, Indonesia, \\ Email:nellyana_fh@unsyiah.ac.id \\ ${ }^{4}$ Faculty of Law,Universitas Syiah Kuala, Indonesia, \\ Email: safrinamahmud@unsyiah.ac.id
}

Submitted: January 25, 2021; Reviewed: April 5, 2021; Accepted: May 19, 2021

Article Info

Keywords:

Illegal Logging, Satellite data, Law enforcement, Environmental crime.

DOI:

10.25041/fiatjustisia.v15no3.2166
Indonesia's forest degradation which is triggered by decades of uncontrolled deforestation has caused massive tropical forest depletion. The same situation also happened to Aceh's forest whose forest areas have been shrinking from year to year. Indication of the increase in illegal logging is both in Indonesia and especially in Aceh as if showing an indication and an academic conclusion that there is a crucial problem. Therefore, there is a need for a mechanism to create an effective legal role to at least reduce illegal logging that is increasingly prevalent in Indonesia's forests. One of the mechanisms is by using a remote sensing technology approach to monitor the occurrence of illegal logging or other criminal acts in the forest which are considered to be the cause of the loss of Aceh's forest in particular and Indonesia in general. This study aims to find out the use of remote sensing satellite technology to monitor illegal logging in Aceh and to identify the use of satellite imagery by law enforcement officials in Aceh to punish illegal logging offenders. The results showed that law enforcement officers used satellite imagery data on conditions before and after environmental damage in handling illegal logging. However, the data that emerged from LAPAN is rarely used by law enforcement officials to monitor the condition of national forests, especially those in their work areas. Lack of use of satellite data by law 
enforcement officials in the initial tracking to eradicate illegal logging due to their lack of initiative to prevent illegal logging, the physical condition of Leuser protected forest areas which are also close to residential areas, and external issues of areas that make wood from Aceh's forests are traded outside the region and even abroad, as well as the lack of qualifications of law enforcement officials who know the environmental issues.

\section{A. Introduction}

Indonesia is a country with the third-largest tropical forest in the world after Brazil and Zaire, covering an area of 133.7 million hectares and having ecological functions for the globe. ${ }^{1}$ But on the other hand, this ecological function is under pressure due to the emergence of deforestation and forest degradation. Starting because of fires and forest encroachment, illegal logging, and illegal trading triggered by the need for wood for industry, conversion to agricultural land, plantations, settlements, and so on. ${ }^{2}$ The state loss due to various natural and legal events on Indonesian forests is estimated to be the state losing trending rupiah.

In a period of three years (from 2003-2005), for example, tracked state losses due to illegal logging reached 83 trillion rupiah. The three years are estimated to be bigger than the data obtained because there are still many cases of illegal logging that have not been revealed, especially those where the value of the wood has been taken abroad. Meanwhile, the number of illegal logging cases handled by the Police in 2003-2005 was 4,178 cases, while the suspects reached 3,224 people and evidence reached over 1 million $\mathrm{m}^{3}$ of wood. ${ }^{3}$

Indonesia's forest degradation, triggered by decades of uncontrolled logging, has resulted in the massive shrinkage of tropical forests. The rate of forest destruction in the 1985-1997 period was recorded at 1.6 million hectares per year, while in the 1997-2000 period it was 3.8 million hectares per year. This makes Indonesia one of the places with the highest rates of forest destruction in the world. ${ }^{4}$

The same thing happened to Aceh's forests. Based on the Ministry of Forestry's report processed by GeRAK Aceh, the Aceh Forest Area is

\footnotetext{
${ }^{1}$ Badan Litbang Kehutanan dan Taman Nasional Meru Betiri, "Review Tentang Illegal Logging Sebagai Ancaman Terhadap Sumberdaya Hutan Dan Implementasi Kegiatan Pengurangan Emisi Dari Deforestasi Dan Degradasi (REDD) Di Indonesia" (Bogor, 2011).

${ }^{2}$ Josefhin Mareta, "Tindak Pidana Illegal Logging Dalam Konsep Keamanan Nasional," Jurnal Rechts Vinding 5, no. 1 (2016): 35, http://dx.doi.org/10.33331/rechtsvinding.v5i1.3.

3 Winarno and Budyatmojo, "Penegakkan Hukum Tindak Pidana Illegal Loging (Antara Harapan Dan Kenyataan)," Jurnal Yustisia 2, no. 2 (2013): 92-93.

${ }^{4}$ Bambang Tri Bawono and Anis Mashdurohatun, "Penegakan Hukum Pidana Di Bidang Illegal Logging Bagi Kelestarian Lingkungan Hidup Dan Upaya Penanggulangannya," Jurnal Hukum Universitas Islam Sultan Agung (Unissula) 26, no. 2 (2011): 591. 
3,549,813 Ha, this is following the Minister of Forestry Decree No. 170/KptsII/2000 concerning Designation of Forest and Waters Area of Aceh Province. From this amount, the land area of the forest area reaches 3,335,613 hectares. The category shows that the area of Aceh forest area is divided into Protection Forest as much as 52\%, Conservation Forest covering 30\%, the rest is allocated for Limited Permanent Production Forest and Limited Production Forest. From an area of 3,549,813 hectares, around $2.94 \%$ per year the forest always shrinks due to various factors. From shrinking due to illegal logging activities both by companies and the community, mining activities to data manipulation by entrepreneurs in the forestry sector. Illegal logging activities recorded in 2017 reached 1,528 cases with a volume of around 7,421.3 cubic meters of wood. "The number of illegal activities has increased from 2016, where only 1,534 cases of illegal logging were recorded with a volume of 3,665 cubic meters of wood in that year ${ }^{5}$

The indications of the increase in illegal logging crime both in Indonesia and particularly in Aceh seem to show an indication and academic conclusions that there is a crucial problem. Because of that, a new paradigm is needed in dealing with forestry problems that have occurred in Aceh. A process that changes views (mandates) and certain actions in forest management that have been exploitative in nature to gain economic benefits with or without considering socio-cultural and environmental aspects. ${ }^{6}$ Looking for a mechanism to create an effective legal role to at least reduce the illegal logging crime that is increasingly prevalent in Indonesia's forests. As part of the environmental crime, various legal approaches based on contemporary forensic evidence systems have been carried out by the government for illegal logging crimes. These various pieces of evidence are also inseparable from various legal loopholes that are permeated in Law Number 32 of 2009 concerning Environmental Protection and Management.

The provisions of Law Number 32 the Year 2009 underline that environmental criminal law enforcement introduces the threat of minimum and maximum penalties, expansion of evidence, penalties for violations of quality standards, integrated criminal law enforcement, and regulation of corporate crime. The author can understand the provisions regarding the expansion of evidence, one of which is by using a remote sensing technology approach to monitor the occurrence of illegal logging or other criminal acts in forests that are considered to be the cause of the loss of forests in Aceh in particular and Indonesia in general.

Evidence for this can be seen in how much information about forest degradation in Aceh is obtained from satellite imagery released by NGOs

5 Bakri, "Dari Illegal Logging Hingga Perburuan Satwa," Serambinews.com, 2018, http://aceh.tribunnews.com/2018/02/12/dari-illegal-logging-hingga-perburuan-satwa.

${ }^{6}$ M Iskandar et al., Kebijakan Perubahan Kawasan Hutan Dalam Pengelolaan Berkelanjutan (Bandung: Unpad Press, 2010). 
engaged in the environmental sector. The emergence of satellite data released by several Acehnese NGOs has provided several indications that the law enforcement process for future actors does not only involve several normative products but also several other means such as satellite technology (Remote Sensing). The use of the technological approach method in uncovering environmental crimes committed by the perpetrator is one of the means of supporting the orderly power and quality of law enforcement in the environmental sector. ${ }^{7}$

As part of the development of a criminal proof system, the presence of satellite technology can be a forum for policymakers to law enforcement processes for criminals in the environmental sector. ${ }^{8}$ Evidence for this can be seen in Indonesia's policy of issuing a regulation of Law Number 32 of 2009 concerning Environmental Protection and Management (UU-PPLH), which accommodates several approaches, one of which is the satellite technology approach for criminal proof. One method of using satellite technology can be seen in the command and control approach (CAC approach); one of which is monitoring through satellite technology. ${ }^{9}$

Satellite technology, in its capacity as a technology product capable of interpreting images, is used to find out information about the types of forest land cover and the respective area of forest land cover. ${ }^{10}$ Technologically the main source of energy in remote sensing is electromagnetic wave radiation (GEM). GEM is a form of energy that can only be observed through its interaction with an object. The form of this energy is known as visible rays, $\mathrm{X}$ rays, infrared, and microwaves. GEM is part of a continuous spectrum. Through GEM, information about forest conditions due to illegal logging or other identifications can be accurately known. ${ }^{11}$

Law Number 32 of 2009 concerning Environmental Protection and Management in its interpretation provides a view that the technological approach in the aspect of law enforcement is also an integral part of environmental protection and management. ${ }^{12}$ Therefore, the presence of satellite remote sensing technology can reduce illegal logging crime to a minimum.

\footnotetext{
${ }^{7}$ Emil Salim, Lingkungan Hidup Dan Pembangunan (Jakarta: Mutiara Sumber Widya, 1991).

${ }^{8}$ Otto Soemarwoto, Analisis Mengenai Dampak Lingkungan, 8th ed. (Yogyakarta: Gadjah Mada University Press, 1999).

${ }^{9}$ Sukanda Husin, Penegakan Hukum Lingkungan Indonesia (Jakarta: Sinar Grafika, 2009).

${ }_{10}$ Army Mujiani, Akhbar, and Abdul Wahid, "Analisis Spasial Tingkat Perambahan Di Kawasan Hutan Lindung Kecamatan Dolo Selatan Kabupaten Sigi," Jurnal Ilmiah Kehutanan 5, no. 1 (2017): 115.

${ }^{11}$ Achmad Fachruddin Syah, "Penginderaan Jauh Dan Aplikasinya Di Wilayah Pesisir Dan Lautan," Jurnal Kelautan 3, no. 1 (2010): 22.

${ }^{12}$ Priyatna Abdurrasyid, Kedaulatan Negara Di Ruang Udara (Jakarta: Pusat Penelitian Hukum Angkasa/Air and Space Research Center, 1972).
} 
In its implementation, to support the policy of tracking satellite technology for specific interests, LAPAN (National Institute of National Anthem) also holds a National Earth Monitoring Program (SPBM) at the Remote Sensing Utilization Center (Pusfatja), the Aviation Institute and LAPAN carry out the function of disseminating information on the results of research, development, and engineering of remote sensing so that it is easily accessible for users to discover, combine, evaluate and reuse. ${ }^{13}$

The urgency for the use of satellite technology in the form of satellite detection on the degradation of the quality of the forest environment is also inseparable from the problem of high human activity in various fields in the forest environment. The high level of these activities is also both respected and does not pollute the environment which can threaten the quality of the environment, the existence of plants in the forest, and the sustainability of human life. Here the effectiveness of satellite technology can play a role in tracking the quality and condition of the damaged environment by using remote sensing technology that allows monitoring of contaminated land without having to touch objects that must be analyzed. ${ }^{14}$

It is hoped that the negative impact of the policy will create an environment, especially a good and healthy forest environment so that the creation of environmental comfort is as mandated by Indonesia's positive law. ${ }^{15}$ The emergence of remote sensing technology can also be seen as a part of environmental pollution and/or damage control implemented in the framework of preserving environmental functions. This is as stated in Article 14 letter (m) of Law of the Republic of Indonesia Number 32 of 2009 concerning Environmental Protection and Management.

Although the various provisions of the Article mentioned above do not contain separate provisions regarding remote sensing as an instrument for forest environmental protection, the contextual provision of a letter $(\mathrm{m})$ which contains provisions on scientific development can be interpreted if the use of satellite technology for sensing and monitoring facilities has occurred. by human activity can be considered as an instrument of science.

Based on the background explanation above, the problem formulation in this study is as follows: How has the use of remote sensing satellite technology been carried out by Indonesia to monitor the occurrence of illegal logging crime in Aceh and how has satellite image evidence been used by enforcement officials? the law in Aceh to punish the perpetrators of illegal logging?

\footnotetext{
${ }^{13}$ Sarno, "Model Pelakasanaan Deseminasi Informasi Pengideraan Jauh Berbasis Tehnologi Terbuka," Jurnal Penginderaan Jauh Dan Pengolahan Data Citra Digital 13, no. 2 (2016): 74.

14 Sayidah Sulma, Junita Monika Pasaribu, and Nanik Suryo Haryani, "Deteksi Daerah Tercemar Lumpur Asam Mengunakan Data Lansat 7 ETM Berdasarkan Suhu Permukaan Tanah," Jurnal Penginderaan Jauh Dan Pengolahan Data Citra Digital 12, no. 2 (2015): 78 79.

${ }^{15}$ Andi Hamzah, Penegakan Hukum Lingkungan (Jakarta: Sinar Grafika, 2005).
} 
The research method used in this paper is a normative juridical research method with a descriptive-analytical research type approach, which attempts to describe or describe analytically (provide an assessment). ${ }^{16}$ Therefore, this analytical descriptive research is intended as a study to find facts with the correct interpretation. ${ }^{17}$ The approach to this research problem is carried out utilizing a field research approach method (field research), as well as normative juridical methods or literature study ${ }^{18}$ through a review of library materials or secondary data as well as legal comparisons (rechtscomparatief). ${ }^{19}$ Several provisions will be extracted from various relevant sources such as those contained in legal products that have been issued by the state in the form of laws, regional regulations in the form of qanuns, national regulations, and systems to prove illegal logging crimes through satellite imagery. Besides that, the comparison of legal provisions is aimed at obtaining a comprehensive understanding of the legal system, ${ }^{20}$ as well as the background that makes understanding satellite technology a contemporary forensic system in uncovering illegal logging crimes.

\section{B. Discussion}

\section{The Use of Remote Sensing Satellite Technology by Indonesia to Monitor Illegal Logging Crimes in Aceh}

The emergence of satellite image technology as part of the method of investigating environmental crimes has given birth to a new forex method in environmental law. With satellite technology, the magnitude of the damaged area and the potential and ability of the environment to contribute to the balance of the area can be predicted accurately. With satellite technology, various indications that environmental crimes have occurred can also be used as a preventive alternative solution to aggressive environmental damage. The choice of using satellite imagery as part of contemporary forensics to prove that illegal logging has taken place in the proof of mapping is very dependent on the scale of the satellite images produced.

Satellite technology can be considered as part of a new legal solution in reducing illegal logging crimes in Indonesia, as well as an environmental solution in overcoming the extensive degradation of Indonesia's forests, especially Aceh's forests. The emergence of satellite technology has also made

\footnotetext{
${ }^{16}$ Peter Mahmud Marzuki, Pengantar Ilmu Hukum (Jakarta: Kencana, 2008).

${ }^{17}$ Mohammad Nazir, Metode Penelitian (Jakarta: Ghalia Indonesia, 1999).

${ }_{18}$ Sunarjati Hartono, Kapita Selekta Perbandingan Hukum (Bandung: Citra Aditya Bakti, 1991).

${ }^{19}$ Sunarjati Hartono, Penelitian Hukum Di Indonesia Pada Akhir Abad Ke 20 (Bandung: Alumni, 1994).

${ }^{20}$ Ade Maman Suherman, Pengantar Pembandingan Sistem Hukum (Civil Law, Common Law, Hukum Islam) (Jakarta: PT. Raja Grafindo Persada, 2004). 
people aware of the importance of technical support in maintaining the role of the environment and the role of natural resources in life of the universe. ${ }^{21}$

In Indonesia, the use of satellite technology to monitor environmental crimes has also been widely used. This includes cases of illegal logging. The real manifestation of this awareness is the establishment of a multi-mission earth station in Pare-Pare (South Sulawesi) and a data processing station at Pekayon, the National Aeronautics and Space Agency (LAPAN), Jakarta. ${ }^{22}$

The implementation of satellite monitoring activities is also independent of the role and function of LAPAN itself as an organizer of the information dissemination function (DI) as an organizer in the space sector. Based on the Law of the Republic of Indonesia Number 21 of 2013 concerning Space, what is meant by the organizer of space is any activity of exploration and exploitation of space carried out, both on and from the earth, air space, and space (Article 1 Paragraph 4). Space activities include activities to use data and disseminate information (Article 15 Paragraph 1 letter d).

LAPAN has made many extraordinary technical contributions in suppressing environmental crimes in Indonesia, especially in illegal logging cases. Concerning the prevention of illegal logging, the Ministry of Forestry and LAPAN has held a Memorandum of Understanding (MoU) by scheduling two goals of cooperation, including the first to implement a program of planning, exploiting, and developing bioenergy based on energy forests. The second is implementing, monitoring, and evaluating as well as monitoring forests and forest coverage through satellite imagery. ${ }^{23}$

The aim of the MoU is that it is hoped that the implementation of forest utilization in the future will be more well-coordinated and that things will not happen that could harm the country in the future. Referring to the development of appropriate remote sensing technology for law enforcers to uncover illegal logging crimes, the Ministry of Forestry and the Environment and the LAPAN continue to engage various parties, both domestic and foreign, as partners in providing data on the condition of Indonesia's national forests. ${ }^{24}$

A concrete example of this can be seen in the collaboration between the Ministry of Forestry and Environment and LAPAN with the Geospatial Information Agency (BIG) in providing high-resolution satellite imagery. The report from the satellite data is used as a reference for interpreting satellite image data manually (on-screen digitization) which can impact land cover

\footnotetext{
${ }^{21}$ Pramudya Sunu, Melindungi Lingkungan Dengan Menerapkan ISO 14001 (Jakarta: PT Gramedia Widiasarana Indonesia, 2001).

${ }^{22}$ Elly Nurmazily, Public Relations Officer / PPID LAPAN, Interview, 20 September 2018.

${ }^{23}$ Wiwiet, staff of Director of Inventory and Monitoring of Forest Resources, Directorate General of Forestry Planning and Environmental Management, Ministry of Environment and Forestry, Republic of Indonesia, Interview 26 September 2018.

${ }^{24}$ Wiwiet, staff of Director of Inventory and Monitoring of Forest Resources, Directorate General of Forestry Planning and Environmental Management, Ministry of Environment and Forestry, Republic of Indonesia
} 
activities. LAPAN provides corrected satellite image data that is ready to be used in satellite image interpretation activities. One of the satellite interpretation activities of illegal logging activities is through the assessment of biomass which causes critical factors that affect changes in vegetation cover and carbon emissions from other consequences of forest degradation such as forest fires. ${ }^{25}$

The same thing also happened in Aceh's forest, LAPAN's very significant contribution in providing the most up-to-date data on the condition of Aceh's forestry. Based on data from satellite imagery of Aceh's forests, especially forests included in the districts of West Aceh, South Aceh, Subususallam City, and Aceh Singkil Regency, so far known as the conservation area of the Mount Lauser National Park (TNGL) continues to experience shrinking. The Decree of the Minister of Forestry No. 276/Kpts-II/1997, stated that the area of TNGL in Aceh and North Sumatra reached 1,094,692 hectares. In its development, based on satellite image data, the area of this national park has decreased to 838,872 hectares, based on the Decree of the Minister of Forestry No.6589/Menhut-VII/KUH/2014. In Aceh, the area of Leuser is following the Decree of the MenLHK No. 103/MenLHK-II/2015 reached 625,115 hectares. ${ }^{26}$

Geographic Information System (GIS) data, taken by the Aceh Forest, Nature and Environment Foundation (HaKA) 2017, currently forest cover in TNGL is 592,454 hectares. Or damaged around 32,661 hectares. However, in its development, the forest in the TNGL area continues to shrink, even though in 2018 the rate of damage has decreased compared to the previous year. However, forest destruction is still the homework of the Aceh government now to continue to reduce the rate of environmental destruction. The main motive for a large number of criminal acts of illegal logging in the TNGL forest area is inseparable from the high demand for basic wood materials for housing purposes as well as the policy of clearing new land by people in conservation forest areas for plantation purposes. ${ }^{27}$

The emergence of the use of technology by law enforcement officials, both the police, prosecutors, and judges to prove environmental crimes, seems to reinforce the importance of increasing the central role of satellite image technology as part of contemporary forensics. The role of satellite imagery technology in providing GPS pinpoints and even periodic satellite imagery

\footnotetext{
${ }^{25}$ Suwarsono, Any Zubaidah, and M. Rokhis Khomaruddin, “Analisis Karakteristik Temperatur Area Terbakar (Burned Area) Menggunakan Data Landsat-8 TIRS Di Kalimantan," Jurnal Penginderaan Jauh Dan Pengolahan Data Citra Digital 13, no. 1 (2016): 14, https://doi.org/10.30536/j.pjpdcd.2016.v13.a2933.

${ }^{26}$ Agung Dwinurcahya, Manager of the Geographic Information System (GIS) of the Aceh Natural Forest and Environment Foundation (HAkA), Interview 28 July 2019.

27 Elly Nurmazily, Public Relations Officer / PPID LAPAN

276
} 
images of conditions after and before the occurrence of environmental crimes at the scene of the crime.

Especially for the Ministry of Forestry and the Environment, periodic reports provided by LAPAN and BIG through satellite imagery technology have been used as the main source of data for monitoring forest resources. The data provided is used as the latest information regarding the condition of Indonesia's forests as a whole. Monitoring of forest conditions and forest resources carried out by the Ministry of Environment and Forestry, in this case, the Directorate of Forest Resources Inventory and Monitoring (Dit. IPSDH) is the monitoring of land cover throughout Indonesia. Reports from the satellite data are used as a reference for interpreting satellite image data manually (on-screen digitization) which can impact land cover activities. LAPAN provides corrected satellite image data that is ready to be used in satellite image interpretation activities. BIG provides a base map that is used as a reference in interpreting satellite imagery. The interpretation activity itself is carried out by BPKH I-XXII which is then coordinated, compiled and quality controlled by Dit. IPSDH. BPKH's involvement in forest resource monitoring activities is to improve the quality of the data produced. ${ }^{28}$

To maintain product continuity and improve the work process of making land cover data, a collaboration between LAPAN and KLHK was carried out for the preparation of Landsat data. The two institutions have had a Memorandum of Understanding (MoU) for work related to remote sensing since 2004 and in 2015 it has been renewed. Concrete evidence of the results of the MoU in the law enforcement process carried out by the Ministry of Environment and Forestry can be seen from the Land Cover Periodization data that has been carried out by the Ministry of Forestry from the satellite images submitted by LAPAN. This data is evidence and concrete action of law enforcement in the field of illegal logging:

1. Period 1 (before 2000), used all available data including analog data, and Landsat hard copies depicted manually and digitally. For Landsat satellite image data, most use softcopy in CCT format or hard copy, not the same between years but still in period 1. In this period the available data is the best and only data to produce the land cover. Products from Period 1 that were produced were the result of the National Forest Inventory (NFI) which was later published in Holmes (2000, 2002).

2. Period 2 (2000-2009) is a period where land cover data is generated using only digital data. However, the manual method of classification (interpretation) that is used takes a long time, mainly due to the limited work experience of interpreters in this period. As an alternative for quick reporting, SPOT Vegetation 1000 meters and MODIS 250 meters are used.

\footnotetext{
${ }^{28}$ Direktorat Inventarisasi dan Pemantauan Sumber Daya Hutan, "Peta Penutupan Lahan Indonesia," Kementerian Lingkungan Hidup dan Kehutanan, n.d., http://webgis.menlhk.go.id:8080/pl/pl.htm.
} 
3. Period 3 (2009 onwards), Landsat was used as the main data because there were no more data acquisition problems. In this period a single geodatabase was used and improvements were made to the previous period's land cover data by using one main data source (Landsat) to make land cover data more consistent and facilitate the subsequent manufacturing process. ${ }^{29}$

The use of high-resolution satellite imagery covering a large area can provide complete and up-to-date data, which is the most appropriate resource for regional planning and structuring. Meanwhile, the Multiband LandsatTM image data can provide thematic data according to your needs so that you can find out all types of land cover (vegetation coverage) with all its characteristics. For example, the Ministry of Forestry can identify the types and sizes of trees from a forest area and the distribution of hotspots that cause forest fires and forest destruction by illegal logging perpetrators.

\section{Use of Evidence Satellite Imagery by Law Enforcement Officials in Aceh to Punish Perpetrators of Illegal Logging}

Law Number 41 the Year 1999 concerning Forestry accommodates the community's opportunity to utilize the forest to obtain optimal benefits for the economic welfare of the community. However, in its development, many forestry crimes such as illegal logging occur in this type of forest and are carried out in various modes. ${ }^{30}$

The presence of satellite technology has contributed greatly to the process of disclosing illegal logging environmental crimes. Besides, the development of satellite imagery from year to year, which continues to increase, is very helpful for law enforcement officials in exposing illegal logging crimes, such as the development of ALOS technology (Advance land Observing Satellite) with AVNIR2 sensor (Advance Visible and Near Infrared Radiometer type-2) is a new type of satellite owned by Japan. ${ }^{31}$

Nationally, the satellite sensing capacity owned by the Indonesian nation is handled by the National Aeronautics and Space Agency (LAPAN), based on the implementation of Law No. 21 of 2013 concerning Space. In strengthening capacity for the benefit of law enforcement in the environmental sector, the government issued Presidential Instruction No. 6 of 2012, concerning space where the provision of remote sensing data is carried out by LAPAN, the others are left to use, aimed at increasing the efficiency of the

\footnotetext{
${ }^{29}$ Confirmation data with Wiwiet, staff of the Director of Inventory and Monitoring of Forest Resources, Directorate General of Forestry Planning and Environmental Management, Ministry of Environment and Forestry of the Republic of Indonesia, where the data has been converted in the official website of the Ministry of Forestry and the Environment at source http: //webgis.menlhk.go. id: 8080 / pl / pl.htm. Accessed 3 August 2018.

${ }^{30}$ Iskandar et al., Kebijakan Perubahan Kawasan Hutan Dalam Pengelolaan Berkelanjutan.

${ }^{31}$ Tamaluddin Syam et al., "Pemanfaatan Citra Satelit Dalam Mengidentifikasi Perubahan Penutupan Lahan: Studi Kasus Hutan Lindung Register 22 Way Waya Lampung Tengah," Jurnal Globe 14, no. 2 (2012): 146-56.
} 
state budget by preventing duplication in the procurement of remote sensing data. With this high-resolution image of LAPAN, BIG is expected to be able to complete large-scale mapping that can be used for various purposes, one of which is to prove illegal logging environmental crimes by national law enforcement officials.

The presence of a central role played by LAPAN in its capacity to provide the latest data on Indonesia's territorial conditions is also strengthened by legal policies in the form of Presidential Instruction Number 6 of 2012 concerning the Provision, Use, Quality Control, Processing, and Distribution of HighResolution Remote Sensing Satellite Data, Lapan and the Geospatial Information Agency are working together to provide satellite imagery and create maps, and submit very high-resolution remote sensing satellite data to all ministries and agencies. ${ }^{32}$

This is reasonable because the use of very high-resolution satellite imagery can be applied to manage the condition of Indonesia's national forestry and especially Aceh, which from day to day is shrinking in number due to various factors, one of which is illegal logging. Data from satellite imagery can also support good governance. The implementation of the policy can be seen from the use of satellite image data by law enforcement officials to monitor the condition of national forestry, especially those in their legal work areas. This is also the case in the forest area of Aceh and some data from satellite imagery are used to strengthen the prosecution suit for the perpetrators of illegal logging in Aceh.

In terms of legal qualifications, data on satellite imagery, whether the current image of the location of the forest where the illegal logging crime was committed, the Global Positioning System (GPS) locus delicti point, or place where the illegal logging was committed is recognized as electronic evidence. In several cases, several law enforcement officials received case files with the Global Positioning System (GPS) locus delicti inclusion or the place where illegal logging was committed as evidence in court by law enforcement officials. ${ }^{33}$ However, the data that emerged from the LAPAN were rarely used by law enforcement officials to monitor the condition of national forestry, especially those in their legal work areas.

It is rare for law enforcement officers to use satellite imagery data in the initial tracking of illegal logging crimes because they are still passive with the initiative to prevent illegal logging crimes. Many of the law enforcement actions are carried out based on public reports and not on periodic digital surveys of the condition of national forestry conservation areas in their jurisdictions. With this digital data, at least the police can always calculate the potential for illegal logging or other crimes that occur in Aceh's national

\footnotetext{
${ }^{32}$ Elly Nurmazily, Public Relations Officer / PPID LAPAN

${ }^{33}$ Zulfadli, S.H., M.H, Chairman of the Melauboh District Court, West Aceh District, Interview, 21 July 2019.
} 
conservation forest. Likewise, the capacity of other law enforcement officers such as police, prosecutors, and judges who have qualification certificates for attorneys or environmental judges is minimal or even non-existent. ${ }^{34}$

In some cases, even law enforcement officials in strengthening the demands of court verdicts have summoned expert staff from the BKSDA forestry service to provide details about the locations where the crimes occurred. However, in the capacity of expert witnesses, the validity of the information submitted is also difficult to be used as a reference by the judge in court because the expert witness concerned is also not a person who has the qualification of mapping expertise in the satellite field. This issue is also an obstacle for law enforcement officials in court who may suspect that the suspect rejects expert testimony given in court due to the qualifications of an expert witness who does not have the qualifications as an expert in satellite mapping. ${ }^{35}$

Many cases of illegal logging that occurred in Aceh in the evaporation mechanism are still based on public reports. The use of satellite imagery data is widely used in establishing the locations of illegal logging crimes committed by law enforcement officials at the time of making a Case Report (BAP). The data often includes coordinate data based on the GPS locus delicti or the place where the illegal logging crime occurred. The main reason for the absence of elements to strengthen the lawsuit by accompanying satellite image evidence in the lawsuit against the perpetrators of illegal logging crime is because of the duties and functions of the prosecutor itself as regulated in Law No. 16 of 2004 concerning the Attorney General's Office of the Republic of Indonesia, Article 1 point 1 , which one of the tasks is to carry out certain cases and for that purpose can carry out additional examinations before being delegated to a court which in its implementation is coordinated with the investigator. ${ }^{36}$

As part of a special criminal act in the environmental sector, Aceh law enforcers, especially in the Southeast Aceh District Prosecutor's Office, also experience a shortage of experts, especially prosecutors with qualifications in environmental matters. Besides, it is also difficult to present national experts with qualifications to understand satellite image techniques. These obstacles also impact the difficulty of the prosecutor to prove the crime in court. The same thing was faced by the Aceh Landmarks Police, who stated that they left satellite image evidence aside for the perpetrators of illegal logging. Another reason is that the average law enforcement process carried out by the police within the jurisdiction of the Aceh Tamiang Police is based on community

\footnotetext{
${ }^{34}$ Zulfadli, S.H., M.H, Chairman of the Melauboh District Court, West Aceh District

${ }^{35}$ Rahmat Nurhidayat S.H, South Aceh Public Prosecutor (JPU), Interview 23 July 2019.

${ }^{36}$ Fitrah, S.H., Chairman of Public Prosecutor, Southeast Aceh, Interview 10 October 2018. 280
} 
reports and also instructions from the center regarding the eradication of illegal logging crimes. ${ }^{37}$

Another problem that causes law enforcement officials to rarely use satellite imagery tracking illegal logging crimes in their jurisdiction is also due to the physical condition of the forest in the lusher forest area of Lueser National Park which is also close to residential areas. Many of the residents' settlements are located deep within protected and conservation forest areas and far from where they existed before the government designated their residential areas as conservation areas. Many of the residents who live in conservation forest areas do not know that their residential area is a conservation forest area that has been designated by the government. This problem can be said to be a classic problem that eventually resulted in conflicts with residents who live in conservation forest areas. And many of these conflicts arise in production forest areas. ${ }^{38}$

This problem also arises from the issuance of plans and maps of conservation forest areas that are not in sync with the conservation maps set by the government. Many of the government policies in the form of submitting forest management for industrial purposes to certain companies also cover areas of land owned by residents who have lived for generations before their residential areas were designated by the government as forest areas for certain purposes such as conservation and industry. This problem later led to conflicts between residents and companies holding certain rights over forest areas. Therefore, comprehensive government efforts are needed to establish a clear mapping of forests owned by the state.

Other developments that have also led to the emergence of illegal logging crimes are also caused by external problems in the area where timber from Aceh's forests is traded outside the region and even abroad. This can be seen in the illegal logging case that occurred in East Aceh District. As an area in the Province of Nanggroe Aceh Darussalam (NAD), geographically, the area of forest in that area is divided into: (1). In land forest areas with concentrations of rain and wet forest typologies in mountainous geographic areas; (2). Coastal forest areas with concentrations of mangrove forests located on the seashore have a typology as forest areas that function as a deterrent to marine abrasion. ${ }^{39}$ Out of the two forest typologies, the number of illegal logging acts occurred in coastal areas. This is due to external factors of demand for charcoal raw materials from abroad, especially Singapore, which mostly grows on the east coast of East Aceh and Langsa City.

Based on the report of the East Aceh Prosecutor's Office from 2016 to 2017, it was recorded that 17 cases of illegal logging were handled, which

${ }^{37}$ Iptu Kabri, S.H, Kanit Reskrim, Police Resort, Southeast Aceh, Interview 11 Oktober 2018.

38 Suprayitno, Kasat Reskrim, Police Resort, Aceh Singkil District. 23 July 2019.

39 Erni, Staf KPH (Kesatuan Pengelolaan Hutan) Langsa City, Nanggroe Aceh Darusallam, Interview 16 Oktober 2018. 
involved many individual perpetrators. Out of all the perpetrators of the illegal logging crime, all admit to having acted personally. And all the locations of these crimes were committed in inland forest areas which fall within the scope of the East Aceh Regency. Meanwhile, the majority of criminal acts of illegal logging that occur in the jurisdiction of Southeast Aceh are committed by people or groups of people, either living in the vicinity of the forest or even far from the forest who do not have the legal right to cut trees. This is reasonable because of the economic problems that have plagued the community and the large need for wood raw materials for various industries, which has caused them to engage in illegal logging activities. This situation then raises a stigma that it is as if illegal logging is not an illegal activity carried out in secret, but has become a promising economic opportunity and has become a daily work. The phenomenon of illegal logging is no longer just a forestry problem, but a multi-party problem that requires a lot of related parties to solve. This includes monitoring patterns using technological approaches, one of which is satellite technology.

Based on the results of reports on illegal logging crimes in mid-2018, the structural patterns of illegal logging crimes mostly occur in the coastal areas of East Aceh. As an area that also has a coastal typology, the coastal area of East Aceh is also overgrown with mangrove forests which not only function as a deterrent to sea abrasion but also serve as a place of social livelihood for the community, especially fishermen looking for fish, crabs, and shellfish. However, in the middle of 2017-2018, the condition of the mangrove forests in East Aceh continued to shrink and was suspected to be due to illegal logging. The emergence of shrinkage of mangrove forests is also based on the results of satellite imagery, in its law enforcement capacity, it requires a deeper study both from the aspects of legal, social, and ecological studies.

Legally, this indication can be seen from the number of reports received by the community from the police regarding illegal logging against mangrove forests in East Aceh. Another indication is also due to a large number of requests from outside parties, especially Malaysia and Singapore for charcoal whose main raw material comes from mangrove trees. Besides, the large amount of mangrove wood is used as a building construction material from various infrastructures that are being built by the community and the government. Many of these mangrove trees are used as pillars to support the foundation for the floor of a building that is built on more than one floor.

Meanwhile, socially and ecologically, this indication can be seen from the rarity of fishermen to find fish and some other species that live in areas that have mangrove typologies such as fish, crabs, shrimp, and certain shellfish. The loss of a number of this biota is also accompanied by the loss of the ecological function of mangroves as a barrier to land from the dangers of sea abrasion. A number of these indications can also be seen from satellite data on how the ecological position of the mangrove forest coverage in East Aceh and 
measuring the extent to which the possibility of illegal logging has occurred. The identification of mangrove forest destruction in Aceh, especially East Aceh, is currently still based on satellite imagery data and information that intelligently entered Kajari Aceh Timur, and until now none of the perpetrators have been arrested and charged by Kasiswa Aceh Timur. This is reasonable because the concentration of law enforcement against illegal logging in East Aceh is more focused on wet and trophic forest areas in mountainous geographic areas. ${ }^{40}$

The Aceh province, especially Langsa City and East Aceh District, is an area geographically adjacent to the Malacca Strait and connects with the most advanced economic axis of the Asean region, especially Malaysia, Thailand, and Singapore. The demand for charcoal from Aceh's mangrove forests is so great to support the industrial needs of the three countries, particularly Malaysia and Thailand. Broadly speaking, illegal logging that occurs in Aceh, especially East Aceh District and Langsa City, is divided into forest encroachment and illegal logging. By definition, forest encroachment as referred to in the Elucidation of Article 50 Paragraph (3) Letter (a) and (b), Law No. 41 of 1999 concerning Forestry are;

a. What is meant by working in a forest area is cultivating land in a forest area without obtaining permission from an authorized official, among others for plantations, for agriculture, or other businesses. What is meant by using forest areas is utilizing forest areas without obtaining permission from authorized officials, among others for tourism, grazing, camping, or use of forest areas that are not following the permits granted. What is meant by occupying forest areas is controlling forest areas without obtaining permission from authorized officials, among others, to build residences, buildings, and other buildings.

b. What is meant by encroachment is clearing forest areas without obtaining permission from a competent official. ${ }^{41}$

When viewed from the category of actions and the resulting consequences, the provisions of criminal acts formulated in Article 50 paragraph (3) letter (a) of Law Number 41 of 1999 concerning Forestry, are still categorized as forest encroachment even though they are not explicitly referred to as forest encroachment. . In Article 50 paragraph (3) letter a of the Forestry Law, it is stated that "illegally working and / or using and / or occupying forest areas" is an act that is criminalized and punishable by criminal penalties as contained in Article 78 paragraph ( 1) Law Number 41 of 1999 concerning Forestry. In the elucidation of Article 50 paragraph (3) letter (a), it is stated that these activities are, among others, for cultivation, for agriculture, or other businesses, for tourism, grazing, camping, or the use of forest areas that are

\footnotetext{
${ }^{40}$ Hasbulloh Syambas, S.H., M.H, Chariman of Public Prosecutor, East Aceh, Interview, 18 Oktober 2018.

${ }^{41}$ Article 50 Paragraph (3) Letter (a) and (b), Law no. 41 of 1999 concerning Forestry.
} 
not under the permit given, for building residential places, buildings, and other buildings. The elucidation of this article is the same as the modus operandi of illegal logging crimes that occurred on the coast of East Aceh. Another problem that has also led to the emergence of illegal logging crime is also the social problem of the community living around the forest, which still uses wood as a building commodity for housing. Besides the high cost of wood raw materials for various furniture industries.

\section{Conclusion}

The use of satellite technology in monitoring environmental crimes has also been widely used. This includes cases of illegal logging. LAPAN has made many extraordinary technical contributions in suppressing environmental crimes in Indonesia, especially in illegal logging cases. One of the satellite interpretation activities of illegal logging activities is through the assessment of biomass which causes critical factors that affect changes in vegetation cover and carbon emissions from other consequences of forest degradation such as forest fires. The same thing also happened in Aceh's forest, LAPAN's very significant contribution in providing the most up-to-date data on the condition of Aceh's forestry. The role of satellite imagery technology in providing GPS pinpoints and even regular satellite images of the conditions after and before the environmental crime at the scene of the crime occurs and this data becomes data used by law enforcement officials in punishing perpetrators of illegal logging. Therefore, it is recommended that with the prevention of illegal logging criminal acts, the Ministry of Forestry and LAPAN hold more Memorandum of Understanding (MoU) with various institutions both from outside (satellite owners) and build a satellite data server that is connected to every national law enforcement agency regarding datathe latest data on the condition of national forests in each jurisdiction.

In terms of legal qualifications, data on satellite imagery, whether the current image of the location of the forest where the illegal logging crime was committed, the Global Positioning System (GPS) locus delicti point, or place where the illegal logging was committed is recognized as electronic evidence. However, the data that emerged from the LAPAN were rarely used by law enforcement officials to monitor the condition of national forestry, especially those in their legal work areas. Law enforcement officers rarely use satellite imagery data in the initial tracking of illegal logging crime because they are still passive with the initiative to prevent illegal logging crimes, the physical condition of the forest in the protected area of Lueser National Park which is also close to residential areas, and external problems in the area that make wood from Aceh forests are traded outside the region and even abroad, as well as the lack of qualifications of law enforcement officials who have environmental qualifications. Therefore, it is recommended that the government prepare more experts, especially law enforcement officers who 
are qualified in the field of satellite expertise, especially satellite sensing. Besides also strengthening the quality of satellite imagery that has high spatial resolution and is very effective in detecting the appearance of the quality of forest functions as an ecological object on the earth's surface. The use of satellite images with high resolution from the resulting images will be very useful in classifying forest areas that are thought to have lost their function as an environmental buffer due to illegal logging or information about forest areas that have been destroyed and can no longer carry out their function as an environmental buffer.

\section{References}

Abdurrasyid, Priyatna. Kedaulatan Negara Di Ruang Udara. Jakarta: Pusat Penelitian Hukum Angkasa/Air and Space Research Center, 1972.

Bakri. "Dari Illegal Logging Hingga Perburuan Satwa." Serambinews.com, 2018. http://aceh.tribunnews.com/2018/02/12/dari-illegal-logginghingga-perburuan-satwa.

Bawono, Bambang Tri, and Anis Mashdurohatun. "Penegakan Hukum Pidana

Di Bidang Illegal Logging Bagi Kelestarian Lingkungan Hidup Dan Upaya Penanggulangannya." Jurnal Hukum Universitas Islam Sultan Agung (Unissula) 26, no. 2 (2011): 591.

Betiri, Badan Litbang Kehutanan dan Taman Nasional Meru. "Review Tentang Illegal Logging Sebagai Ancaman Terhadap Sumberdaya Hutan

Dan Implementasi Kegiatan Pengurangan Emisi Dari Deforestasi Dan Degradasi (REDD) Di Indonesia." Bogor, 2011.

Hamzah, Andi. Penegakan Hukum Lingkungan. Jakarta: Sinar Grafika, 2005. Hartono, Sunarjati. Kapita Selekta Perbandingan Hukum. Bandung: Citra Aditya Bakti, 1991.

—. Penelitian Hukum Di Indonesia Pada Akhir Abad Ke 20. Bandung: Alumni, 1994.

Husin, Sukanda. Penegakan Hukum Lingkungan Indonesia. Jakarta: Sinar Grafika, 2009.

Hutan, Direktorat Inventarisasi dan Pemantauan Sumber Daya. "Peta Penutupan Lahan Indonesia." Kementerian Lingkungan Hidup dan

Kehutanan, n.d. http://webgis.menlhk.go.id:8080/pl/pl.htm.

Iskandar, M, Daud Silalahi, Djuhendah Hasan, and Ida Nurlinda. Kebijakan

Perubahan Kawasan Hutan Dalam Pengelolaan Berkelanjutan.

Bandung: Unpad Press, 2010.

Mareta, Josefhin. "Tindak Pidana Illegal Logging Dalam Konsep Keamanan

Nasional." Jurnal Rechts Vinding 5, no. 1 (2016): 35. https://doi.org/http://dx.doi.org/10.33331/rechtsvinding.v5i1.3.

Marzuki, Peter Mahmud. Pengantar Ilmu Hukum. Jakarta: Kencana, 2008. Mujiani, Army, Akhbar, and Abdul Wahid. "Analisis Spasial Tingkat 
Perambahan Di Kawasan Hutan Lindung Kecamatan Dolo Selatan

Kabupaten Sigi.” Jurnal Ilmiah Kehutanan 5, no. 1 (2017): 115.

Nazir, Mohammad. Metode Penelitian. Jakarta: Ghalia Indonesia, 1999.

Salim, Emil. Lingkungan Hidup Dan Pembangunan. Jakarta: Mutiara Sumber Widya, 1991.

Sarno. "Model Pelakasanaan Deseminasi Informasi Pengideraan Jauh Berbasis Tehnologi Terbuka." Jurnal Penginderaan Jauh Dan Pengolahan Data Citra Digital 13, no. 2 (2016): 74.

Soemarwoto, Otto. Analisis Mengenai Dampak Lingkungan. 8th ed. Yogyakarta: Gadjah Mada University Press, 1999.

Suherman, Ade Maman. Pengantar Pembandingan Sistem Hukum (Civil Law, Common Law, Hukum Islam). Jakarta: PT. Raja Grafindo Persada, 2004. Sulma, Sayidah, Junita Monika Pasaribu, and Nanik Suryo Haryani. "Deteksi

Daerah Tercemar Lumpur Asam Mengunakan Data Lansat 7 ETM Berdasarkan Suhu Permukaan Tanah." Jurnal Penginderaan Jauh Dan Pengolahan Data Citra Digital 12, no. 2 (2015): 78-79.

Sunu, Pramudya. Melindungi Lingkungan Dengan Menerapkan ISO 14001. Jakarta: PT Gramedia Widiasarana Indonesia, 2001.

Suwarsono, Any Zubaidah, and M. Rokhis Khomaruddin. "Analisis Karakteristik Temperatur Area Terbakar (Burned Area) Menggunakan Data Landsat-8 TIRS Di Kalimantan." Jurnal Penginderaan Jauh Dan Pengolahan Data Citra Digital 13, no. 1 (2016): 14. https://doi.org/10.30536/j.pjpdcd.2016.v13.a2933.

Syah, Achmad Fachruddin. "Penginderaan Jauh Dan Aplikasinya Di Wilayah Pesisir Dan Lautan." Jurnal Kelautan 3, no. 1 (2010): 22.

Syam, Tamaluddin, Arif Darmawan, Irwan Sukri Banuwa, and Kuswibowo Ningsih. "Pemanfaatan Citra Satelit Dalam Mengidentifikasi Perubahan

Penutupan Lahan : Studi Kasus Hutan Lindung Register 22 Way Waya Lampung Tengah." Jurnal Globe 14, no. 2 (2012): 146-56.

Winarno, and Budyatmojo. "Penegakkan Hukum Tindak Pidana Illegal Loging (Antara Harapan Dan Kenyataan)." Jurnal Yustisia 2, no. 2 (2013): 92-93. 